\title{
Association Between Body Mass Index and Caries Lesions in Preschool Children in Santiago, Chile
}

\author{
Asociación entre Lesiones de Caries y Estado Nutricional \\ en Niños Preescolares de la Región Metropolitana
}

\author{
G. Rodríguez; R. Cabello; I. Urzúa; M. Reyes; S. Faleiros; B. Ruiz \& J. Sánchez
}

RODRÍGUEZ, G.; CABELLO, R. ; URZÚA, I.; REYES, M. ; FALEIROS, S.; RUIZ, B. \& SÁNCHEZ, J. Association between body mass index and caries lesions in preschool children in Santiago, Chile. Int. J. Odontostomat., 11(3):369-375, 2017.

ABSTRACT: The objective of the study was to determine the association between caries prevalence and body mass index (BMI) in preschool children in Santiago, Chile. Children aged 2 and 3 years old $(n=342)$ attending 16 nursery schools in Santiago, Chile were examined to record the status of dental caries using the modified criteria of the International Caries Detection and Assessment System (ICDAS II) (International Caries Detection and Assessment System (ICDAS) Coordinating Committee, 2005). BMI was calculated for each of the subjects and their nutritional state was classified as underweight, normal-weight, overweight and obesity according to the WHO. The caries prevalence (ICDAS 2-6 > 0) of the children was $45.9 \%$ (IC $95 \% 40.50$ - 51.21). Data showed that none of the preschoolers were underweight. $39.1 \%$ were classified as normal-weight (IC $95 \% 33.98$ - 44.38), $34.8 \%$ as overweight (IC $95 \% 29.72-39.86$ ) and $26 \%$ as obese (IC $95 \% 21.34$ - 30.96). Normal-weight children had a prevalence of $51.5 \%$ of ICDAS 2-6 lesions and prevalence of $28.3 \%$ of ICDAS 5-6 lesions. Children with overweight had prevalence of 51.4\% ICDAS 2-6 lesions and of 19.3\% ICDAS 5-6 lesions, and obese children of $39.5 \%$ and $25.8 \%$ respectively. Subjects with normal-weight presented a mean of ICDAS 2-6 caries lesions significantly higher $(p<0.05)$ than the rest of the children. In conclusion, normal-weight preschool children presented a higher prevalence of caries lesions than those with overweight and obesity. Iso-BMI was found to be associated with lower dental caries and severity. Future studies should address which specific factors related to overweight in children might be protective against dental caries.

KEY WORDS: early childhood caries, childhood obesity, dental caries, obesity, overweight, decayed.

\section{INTRODUCTION}

Early Childhood Caries (ECC) is an aggressive form of tooth decay. It is defined as the presence of one or more decayed, missing or filled tooth surfaces affecting children under 71 months (Horowitz, 1998; Davies, 1998; Seow, 1998; Ismail \& Sohn, 1999). In Chile the prevalence ranges from $7.8 \%$ to $62.3 \%$ (Mariño \& Onetto, 1995; Echeverria et al., 2003), but the last national unpublished report reveals a caries prevalence of $17 \%$ at 2 and of $50 \%$ at 4 years of age in children in the Santiago Metropolitan Region (Minsal, 2010a).

ECC is recognized as a multifactorial disease and its etiopathogeny is the same as other types of coronary and root caries (Seow), however, it can be modified by multiple factors that are unique to the preschool age. Among these, obesity has been proposed as a possible ECC modifying factor.

Obesity, like tooth decay, has increased significantly in children in recent decades, primarily associated with the intake of high calories and fat diets, and a sedentary life style (Dietz, 1998). In Chile, $9.6 \%$ of children under six years old are obese and $22.6 \%$ are considered overweight (MINSAL, 2007a). A similar trend is observed in Latin America, although the prevalence varies within countries. Markedly, Chile presents the highest prevalence of obesity (Atalah, 2012).

Anthropometry and growth patterns are simple and inexpensive tools to assess nutritional status 
(Martínez Costa \& Pedrón Giner, 2002), one of which is the body mass index (BMI).

The relationship between obesity and tooth decay has been widely studied in many countries and with different results. Willershausen et al. (2004) were able to establish a significant association between increased tooth decay and overweight in both permanent and temporary teeth. Similar results were obtained in studies conducted in Sweden (Larsson et al., 1995; Göthe Mundt, 2003) and preschoolers in Mexico (Vázquez-Nava et al., 2010; Loyola-Rodriguez et al., 2011).

On the other hand, Timanoff and Palmer (Tinanoff \& Palmer, 2000) showed that there is no relationship between BMI and prevalence of caries, even concluded that overweight was associated rather with a low prevalence of caries. Other studies in different parts of the world reinforce these conclusions (Sheller et al., 2009; Wu et al., 2013).

In Chile, studies that relate caries prevalence and nutritional status are scarce and results are contradictory (Cereceda et al., 2010; Zaror et al., 2011; Yévenes et al., 2012). Besides, in most of these studies, DMFT is used as a detection tool, not accounting for non-cavitated caries lesions. This could result in an underestimation of the real prevalence of caries in the population and its relationship with obesity. New detection methods have been developed, among them, the International Caries Detection and Assessment System (ICDAS II), which employs visual criteria for detection of carious lesions in early stages (International Caries Detection and Assessment System (ICDAS) Coordinating Committee) and allows for assessing caries prevalence at the cavitated and non-cavitated level.

Based on the above, the aim of this study was to determine the association between the presence of caries lesions and the nutritional status of preschool children in Chile, using BMI and ICDAS II.

\section{MATERIAL AND METHOD}

Participants, Study design and Sample Size: After the approval of the Faculty of Dentistry scientific ethical committee at the University of Chile, participants were recruited from 16 nursery schools from the Integra Foundation located in the northwestern area of a metropolitan region. In order to be included in this study, the following inclusion criteria were applied: (based on parents reporting on their children's medical history) with or without cavitated caries lesion at baseline whose parents/legal guardians signed the written informed consent form at both baseline examinations. The Integra Foundation focuses on the education of the most socially vulnerable children in Chile. According to epidemiological data, these children represent the group with a high risk of dental caries in the Chilean population (MINSAL, 2010a,b).

Of a total of 520 preschoolers enrolled in the 16 kindergartens selected, 342 children of both sexs, with ages ranging from 2 to 3 years old consented to take part in this cross-sectional observational study.

In order to be included in the study, the following inclusion criteria were applied: healthy children aged 2 to 3 years old (based on parents reporting on their children's medical history) with or without cavitated caries lesions at baseline whose parents/legal guardians signed the written informed consent form at both baseline examinations. Students with any systemic disorders were excluded from the study and those whose parents and/or guardians did not sign or accept informed consent.

\section{Anthropometric measurements}

Measurement of body weight and size: All children were weighed during the morning period, between ten and twelve hours (after breakfast and before lunch) at the kindergardens. The child was positioned barefoot in a temperate room with a minimum of clothing. The measurement was taken on a weighing GAMMA Scale, model HCB, previously calibrated using known weights, determining the weight in kilos to one decimal place. Three separate measurements were performed and the mean was recorded as the final result.

The height was determined with the subject standing in an upright position using a previously calibrated fixed wall stadiometer. Three separate measurements were performed and the mean thereof was recorded as the result.

Anthropometric measurements: A previously trained professional performed the anthropometric measurements. Overweight and obesity were defined using BMI taking the child's weight and dividing by the square of your height. BMI values obtained were compared with the new graphics standard implemented 
RODRígUeZ, G.; CABELLO, R. ; URZÚA, I.; REYES, M. ; FALEIROS, S.; RUIZ, B. \& SÁNCHEZ, J. Association between body mass index and caries lesions in preschool children in Santiago, Chile. Int. J. Odontostomat., 11(3):369-375, 2017.

by WHO MINSAL since 2007, according to age and sex, and classified preschool underweight (less than 3), normal weight (3-85), overweight (85-97) and obese (97 or more). The International Classification Systems for childhood obesity are referred to as 'iso-BMl' categories describing overweight and obesity in children, based on sex and pooled international data for body mass index.

Dental Examinations: Oral examinations were performed in each of the nursery schools by two trained and calibrated examiners $(k<0,70)$ with the assistance of 2 note-takers. The clinical exams were performed in the classrooms using a dental mirror, a WHO probe and LED artificial light. Carious lesions were detected and registered following the ICDAS II criteria. Classification 1 corresponding to the observable white opacity was omitted by air-drying, for not having conditions for drying.

Data analysis. Data were entered into Microsoft Excel 2010 spreadsheets (Microsoft Corporation, Redmond, WA, USA) and analyzed using STATA (version 11.0, StataCorp College Station, Texas, USA). Differences in caries prevalence between groups according to age and body mass index were analyzed for statistical significance using the chi-square test. To measure statistical significance between the number of carious lesions (mean of caries lesions) and nutritional status, analysis of variance (ANOVA) was performed. To measure significance between groups in relation to mean of carious lesions and normal/overweight, $t$ Student $t$ test was used. Adjusted odds ratios (OR) and their $95 \%$ confidence intervals $(\mathrm{Cl})$ were calculated. $\mathrm{P}<0.05$ was considered statistically significant. Finally, regression models were calculated to establish partnership between variables.

\section{RESULTS}

The total number of subjects examined was 342 , of which $167(48.8 \%)$ were male and $175(51.1 \%)$
Table I. Distribution of the sample according to caries prevalence, mean of caries lesions and sex.

\begin{tabular}{lll}
\hline & Female & Male \\
\hline ICDAS 2-6 $>0, \%$ & 56.2 & 45.5 \\
ICDAS 5-6 $>0, \%$ & 24.6 & 24.6 \\
dicdas 2-6mft, mean $_{\text {icdas 5-6mft, mean }}$ & 1.88 & 1.79 \\
d $_{\text {icd }}$ & 0.81 & 0.77 \\
\hline
\end{tabular}

Table II. Distribution of the sample according to nutritional status and sex.

\begin{tabular}{lllll}
\hline Nutritional Status & \multicolumn{3}{c}{ Sex } \\
& \multicolumn{2}{c}{ Male } & \multicolumn{2}{c}{ Female } \\
\cline { 2 - 5 } & $\mathrm{N}$ & $\%$ & $\mathrm{~N}$ & $\%$ \\
Underweight & 0 & 0 & 0 & 0 \\
Normal weight & 70 & 52.2 & 64 & 47.8 \\
Overweight & 51 & 42.8 & 68 & 57.2 \\
Obese & 46 & 51.6 & 43 & 48.4 \\
Total & 167 & 48.8 & 175 & 51.2 \\
\hline
\end{tabular}

were females. The mean age of the population was 2.96 years $(95 \% \mathrm{Cl} 2.92$ to 2.99$)$. Table I shows distribution of the sample according to caries prevalence, mean of caries lesions and sex.

The distribution of the sample according to sex and nutritional status is presented in Table II.

The caries prevalence and mean of caries lesions due to nutritional status is presented in Table III. The subjects with normal weight were the most prevalent nutritional group of carious lesions in ICDAS 2-6 and 5-6. No significant difference between groups $(p=0.161)$ and $(p=0.237)$ were found respectively.

The highest mean as presented subjects with normal weight ( $95 \% \mathrm{Cl} 1.84$ to 2.99 ). In applying the analysis of variance (ANOVA) using nutritional status as an ordinal independent variable, no significant differences between groups of ICDAS 2-6 $(p=0.1212)$

Table III. Caries prevalence and mean of caries lesions according nutritional status.

\begin{tabular}{|c|c|c|c|}
\hline & \multicolumn{3}{|c|}{ Nutriti onal Status } \\
\hline & Normal Weight & Over Weight & Obese \\
\hline ICDAS 2-6 > 0, \% & 51.5 & 51.4 & 39.5 \\
\hline ICDAS 5-6 > 0, \% & 28.3 & 19.3 & 25.8 \\
\hline $\mathrm{d}_{\text {icdas 2-6 }} \mathrm{mft}$, mean & 2.41 & 1.36 & 1.6 \\
\hline $\mathrm{d}_{\mathrm{icdas} 5-6} \mathrm{mft}$, mean & $1.04^{*}$ & $0.62^{*}$ & 0.65 \\
\hline
\end{tabular}


RODRÍGUEZ, G.; CABELLO, R. ; URZÚA, I.; REYES, M. ; FALEIROS, S.; RUIZ, B. \& SÁNCHEZ, J. Association between body mass index and caries lesions in preschool children in Santiago, Chile. Int. J. Odontostomat., 11(3):369-375, 2017.

were found, however differences between groups of subjects with normal weight and overweight subjects of ICDAS 5-6 ( $p=0.009)$ were found.

The caries prevalence ICDAS 2-6 and ICDAS 5- 6 in children diagnosed with iso-BMl (overweight and obesity) did now showed to be significantly different from children diagnosis with normal weight $(p=0.19$ and $p=0.096$ respectively) as can appreciate in Table IV.

Table IV. Caries prevalence and mean of caries lesions in normal subjects versus subjects with iso-BMI.

\begin{tabular}{lcc}
\hline & \multicolumn{2}{c}{ Nutritional Status } \\
& Normal Weight & iso-BMI \\
\hline ICDAS 2-6 $>0, \%$ & 51.5 & 42.3 \\
ICDAS 5-6 $>0, \%$ & 28.3 & 22.1 \\
$\mathrm{~d}_{\text {icdas 2-6 }}$ mft, mean & $2.41^{*}$ & $1.46^{*}$ \\
$\mathrm{~d}_{\text {icdas 5-6 }}$ mft, mean & 1.04 & 0.63 \\
\hline${ }^{*} p<0,01$ & &
\end{tabular}

Likewise, applying the Student $t$ test, there was no statistical difference by associating the mean of caries lesions ICDAS 5-6 with the nutritional status of children with normal weight and iso-BMI. However, considering the mean of caries lesions cavitated and non-cavitated (dicdas 2-6mft) there was a significant difference between groups $(p=0.0011)$.

Finally, Table $V$ shows simple linear regression analysis that was performed to associate the number of caries lesions (ICDAS II = $2-6$ ) as a dependent variable with $\mathrm{BMI}$ as an explanatory or independent variable, obtaining a value of $p=0.039$.

For the logistic regression analysis that associated the prevalence of caries lesions (ICDAS II $=2-6$ ) as a dependent variable with nutritional status (normal weight, overweight and obese), no risk association (OR $=0.8795 \% \mathrm{Cl} 0.66-1.14)$ or statistical significance $(p=0.318)$ were found.

Table V. Logistic and linear regression models.

\begin{tabular}{llll}
\hline Variables & & $\mathrm{P}$ & $\mathrm{IC} 95 \%$ \\
\hline $\mathrm{N}^{\circ}$ caries lesion/ BMI & Coef $=-0.21$ & $\mathbf{0 . 0 3 9}$ & $0.42-0.11$ \\
Prevalence caries lesions / Nutritional Status & OR $=0,87$ & 0.318 & $0.66-1.14$ \\
Prevalence caries lesions / Nutritional Status (dichotomous) & $\mathrm{OR}=0.69$ & 0.097 & $0.44-1.06$ \\
\hline
\end{tabular}

\section{DISCUSSION}

This study found an inverse association between BMI and presence of caries lesions in a sample of preschool children. According to the linear regression analysis, a higher BMI was associated with less number of caries lesions. However, when associating caries prevalence with nutritional status as dichotomous and ordinal variable, no association of risk or statistical difference was found between them.

The caries prevalence found was $45.9 \%$. This result is higher compared to ministerial reports (MINSAL, 2007b; MINSAL, 2009) where the percentage of children aged 2-4 years old, free of carious lesions was $83 \%$ in the Metropolitan Region, Santiago - Chile. This could be because the ministerial studies do not consider non-cavitated caries lesions and thus may underestimate the true damage carious lesions.
Regarding nutritional status, preschool children evaluated had high levels of overweight and obesity. The percentage of children diagnosed with obesity was $26 \%$, higher than that published by the MINSAL for 2010. A possible explanation for this could be that the subjects of the study population belonged to families in poverty and / or social vulnerability and according to the results National Health Survey (2010) (MINSAL, $2010 b)$, this is a condition of special susceptibility in relation to overweight and obesity.

It is known that frequent consumption of refined carbohydrates and sugars are strongly associated with the development of caries lesions and that such consumption is also associated with childhood overweight and obesity (Sheiham, 2001; Malik et al., 2006). It was therefore justifiable to suggest that children with iso-BMI possibly would have a greater probability of caries lesions. However, this was not 
RODRÍGUEZ, G.; CABELLO, R. ; URZÚA, I.; REYES, M. ; FALEIROS, S.; RUIZ, B. \& SÁNCHEZ, J. Association between body mass index and caries lesions in preschool children in Santiago, Chile. Int. J. Odontostomat., 11(3):369-375, 2017.

confirmed in this study. Overweight and obese preschoolers have less prevalence of caries lesions than those with normal weight. Subjects with normal weight have a mean of carious lesions (dicdas 2-6 mft) significantly higher than children with overweight and obesity. These results are consistent with recent studies carried out in Chile and other countries, where no association between caries and obesity was found (Tinanoff \& Palmer; Sheller et al.; Costa et al., 2013). Some authors suggest that overweight might even be a protective factor against the occurrence of caries, as groups of overweight children had a lower rate $\mathrm{dmft}$ (Willershausen et al.; Kopycka-Kedzierawski et al., 2008).

The negative results of this supposed association between obesity and tooth decay can be explained by the preventive oral health policies implemented in the kindergartens and the impact of fluoridation (Buzalaf et al., 2011).

Another explanation could be the change in eating habits of obese children. Studies on eating habits in preschool Chilean conducted show high-energy intake and especially a high fat in obese preschoolers (Kain \& Andrade, 1999; Vásquez et al., 2007).

A comparative study in obese and eutrophic preschool children in the eastern area of Santiago, established that the most significant change in the apparent consumption of nutrients from 1993 to 2003 is the $18 \%$ increase in fat consumption over other nutrients. Furthermore, the FAO report on the nutritional profile of Chile published in 2001 shows an increase in the supply of fat around $45 \%$ and a decrease in carbohydrate intake. This could explain the low prevalence of caries lesions in obese children as fat could be a protective factor against the development of caries lesions by its bacteriostatic role (MeyerLueckel et al., 2015).

A difference of the present study compared to those investigations as references is that these mostly use $\mathrm{WHO}$ criteria for the diagnosis of caries lesions, which considers only those injuries with evident cavitation, and detected by visual clinical examination. In this study ICDAS was used in order to include noncavitated caries lesions.

The same association of nutritional status with the presence of caries lesions was performed, but only including cavitated caries lesions (dicdas 5-6 mft). The results of the association were similar to those found when considering all carious lesions (dicdas 2-6 mft).

One of the limitations of this study is that the data analyzed does not provide evidence of causality as it corresponds to a cross-sectional design. Dental hygiene, diet and topical fluoride exposure were not recorded as strong variables in the subjects of the sample, which may distort the results. Another limitation of this study refers to population nutritional diagnosis. This would have ideally been done on the basis of integrated nutritional diagnosis of children, for which the results of anthropometric indicators plus history and physical data is combined. Therefore, BMI would be insufficient to establish state of adiposity in the pediatric population and could explain the conflicting results exist in the literature regarding this association.

In conclusion, children with normal weight have significantly more caries lesions than those with overweight and obesity. There is an inverse association between BMI and presence of caries lesions in preschool children, and overweight and obesity are not associated with the prevalence of caries lesions. More research is needed to help clarify the association between nutritional status and caries prevalence.

\section{ACKNOWLEDGEMENTS}

The authors of this review received financial support from National Fund for Research and Development in Health, Chile Government (FONIS SA 11i2035) and declare no potential conflicts of interest with respect to the authorship and/or publication of this article.

We declare that all the research has been conducted in full accordance with the World Medical Association Declaration of Helsinki.

RODRÍGUEZ, G.; CABELLO, R. ; URZÚA, I.; REYES, M. ; FALEIROS, S.; RUIZ, B. \& SÁNCHEZ, J. Asociación entre lesiones de caries y estado nutricional en niños preescolares de la Región Metropolitana. Int. J. Odontostomat., 11(3):369-375, 2017.

RESUMEN: La caries dental es una enfermedad crónica multifactorial que afecta a niños denominada Caries Temprana de la Infancia (CTI). Su etiología es multifactorial y se asocia a determinantes biológicos, conductuales y 
sociodemográficos. Entre estos, se ha planteado la obesidad como presunto factor de riesgo para el desarrollo de caries en población infantil. El objetivo de este estudio fue establecer si existía o no asociación entre la presencia de lesiones de caries y el estado nutricional en una muestra de 342 preescolares entre 1 y 4 años de edad, que asisten a jardines infantiles de la Fundación INTEGRA, en la Región Metropolitana de Santiago. Se realizaron exámenes clínicos dentales y medición de la talla y peso. Se calculó IMC para cada uno de los sujetos y su estado nutricional fue clasificado como por debajo del peso adecuado, peso normal o normopeso, sobrepeso y obesidad según los gráficos y tablas de la OMS. La prevalencia total de lesiones de caries (ICDAS II = 2 -6) fue de 45,9\% (IC $95 \%$ 40,59-51,21). EI estado nutricional de la muestra completa fue de $0 \%$ bajo el peso normal, $134(39,1 \%)$ niños presentaron peso normal (IC $95 \%$ 33,98 - 44,38), 119 niños (34,8 \%) presentaron sobrepeso (IC $95 \% 29,72-39,86$ ) y a $89(26 \%$ ) niños se les diagnosticó obesidad (IC $95 \%$ 21,34-30,96). Los sujetos con normopeso presentaron un promedio de lesiones de caries (ICDAS II $=2-6)$ significativamente mayor $(p<0,05)$. Por lo tanto, se puede concluir que los preescolares con peso normal presentaron mayor número de lesiones de caries de acuerdo al criterio ICDAS II, que aquellos preescolares con sobrepeso y obesidad.

PALABRAS CLAVE: caries temprana de la infancia, obesidad infantil, caries dental, obesidad, sobrepeso, lesiones de caries.

\section{REFERENCES}

Atalah, S. E. Epidemiology of obesity in chile. Rev. Med. Clin. Las Condes, 23(2):117-23, 2012.

Buzalaf, M. A. R.; Pessan, J. P.; Honório, H. M. \& ten Cate, J. M. Mechanisms of Action of Fluoride for Caries Control. In: Buzalaf, M. A. R. (Ed.). Fluoride and the Oral Environment. Basel, Karger, 2011. pp.97-114

Cereceda, M. M. A.; Faleiros, C. S.; Ormeño, Q. A.; Pinto, G. M.; Tapia, V. R.; Díaz, S. C. \& García, B. H. Prevalence of dental decay in elementary school children and association with nutritional status. Rev. Chil. Pediatr., 81(1):28-36, 2010.

Costa, L. R.; Daher, A. \& Queiroz, M. G. Early childhood caries and body mass index in young children from low income families. Int. J. Environ. Res. Public Health, 10(3):867-78, 2013.

Davies, G. N. Early childhood caries--a synopsis. Community Dent. Oral Epidemiol., 26(1 Suppl.):106-16, 1998.

Dietz, W. H. Prevalence of Obesity in Children. In: Bray, G. A.; Bouchard, C. \& James, W. P. T. (Eds.). Handbook of Obesity. New York, Marcel Dekker, 1998. pp.93-102.

Echeverria, L. S.; Soto, S. D. \& Zillmann, G. G. The prevalence of nursing caries in 2-4 year old children of the Metropolitan Area. Updated diagnostic. Rev. Dent. Chile, 94:14-8, 2003.

Göthe Mundt, A. K. Oral Health and Risk Factors for Cardiovascular Disease in Children and Adolescents with Obesity. Stockholm, Karolinska Instituet Odontologiska Institutionen, 2003.

Horowitz, H. S. Research issues in early childhood caries. Community Dent. Oral Epidemiol., 26(1 Suppl.):67-81, 1998.
International Caries Detection and Assessment System (ICDAS) Coordinating Committee. Rationale and Evidence for the International Caries Detection and Assessment System (ICDAS II). Ann Arbor, University of Michigan, 2005.

Ismail, A. I. \& Sohn, W. A systematic review of clinical diagnostic criteria of early childhood caries. J. Public Health Dent., 59(3):17191, 1999

Kain, J. \& Andrade, M. Characteristics of the diet and patterns of physical activity in obese Chilean preschoolers. Nutr. Res., 19(2):203-15, 1999.

Kopycka-Kedzierawski, D. T.; Auinger, P.; Billings, R. J. \& Weitzman, M. Caries status and overweight in 2- to 18-year-old US children: findings from national surveys. Community Dent. Oral Epidemiol., 36(2):157-67, 2008.

Larsson, B.; Johansson, I.; Hallmans, G. \& Ericson, T Relationship between dental caries and risk factors for atherosclerosis in Swedish adolescents? Community Dent. Oral Epidemiol., 23(4):205-10, 1995.

Loyola-Rodriguez, J. P.; Villa-Chavez, C.; Patiñio-Marin, N.; AradillasGarcia, C.; Gonzalez, C. \& de la Cruz-Mendoza, E. Association between caries, obesity and insulin resistance in Mexican adolescents. J. Clin. Pediatr. Dent., 36(1):49-53, 2011.

Malik, V. S.; Schulze, M. B. \& Hu, F. B. Intake of sugar-sweetened beverages and weight gain: a systematic review. Am. J. Clin. Nutr., 84(2):274-88, 2006.

Mariño, R. J. \& Onetto, J. E. Caries experience in urban and rural Chilean 3-year-olds. Community Dent. Oral Epidemiol., 23(1):601, 1995.

Martínez Costa, C. \& Pedrón Giner, C. Valoración del Estado Nutricional. En: Protocolos Diagnósticos y Terapéuticos en Pediatría. Tomo 5. Gastroenterología, Hepatología y Nutrición. Madrid, Asociación Española de Pediatría, 2002. pp.375-82.

Meyer-Lueckel, H.; Paris, S. \& Ekstrand, K. Manejo de la Caries Ciencia y Práctica Clínica. Caracas, Amolca, 2015. pp.169.

Ministerio de Salud (MINSAL). Análisis de Situación de Salud Bucal en Chile. Santiago de Chile, Gobierno de Chile, 2010a. Available from: http://web.minsal.cl/sites/default/files/files/ Análisis\%20de\%20Situación\%20Salud\%20Bucal\%20final\%20pdf.pdf

Ministerio de Salud (MINSAL). Departamento de Nutrición y Ciclo Vital División Prevención y Control de Enfermedades Ministerio de Salud. Norma para el Manejo Ambulatorio de la Malnutrición por Déficit y Exceso en el Niño(a) Menor de 6 Años. Santiago de Chile, Gobierno de Chile, 2007a. pp.21-6.

Ministerio de Salud (MINSAL). Diagnóstico en Salud Bucal de los Niños de 2 y 4 Años de Edad que Asisten a la Educación Preescolar en la Zona Norte y Centro del País. Santiago de Chile, Gobierno de Chile, 2009

Ministerio de Salud (MINSAL). Diagnóstico en Salud Bucal de Niños de 2 y 4 Años que Asisten a la Educación Preescolar. Santiago de Chile, Gobierno de Chile, 2007b.

Ministerio de Salud (MINSAL). Encuesta Nacional de Salud ENS 2009-2010. Santiago de Chile, Gobierno de Chile, 2010b. Available from: http://www.redsalud.gov.cl/portal/docs/page/ minsalcl/g_home/submenu_portada_2011/ens2010.pdf

Seow, W. K. Biological mechanisms of early childhood caries. Community Dent. Oral Epidemiol., 26(1 Suppl.):8-27, 1998.

Sheiham, A. Dietary effects on dental diseases. Public Health Nutr., 4(2B):569-91, 2001.

Sheller, B.; Churchill, S. S.; Williams, B. J. \& Davidson, B. Body mass index of children with severe early childhood caries. Pediatr. Dent., 31(3):216-21, 2009.

Tinanoff, N. \& Palmer, C. A. Dietary determinants of dental caries and dietary recommendations for preschool children. J. Public Health Dent., 60(3):197-206, 2000.

Vásquez, F.; Salazar, G.; Rodríguez, M. P. \& Andrade, M. Comparación entre la ingesta alimentaria de preescolares obesos y 
RODRÍGUEZ, G.; CABELLO, R. ; URZÚA, I.; REYES, M. ; FALEIROS, S.; RUIZ, B. \& SÁNCHEZ, J. Association between body mass index and caries lesions in preschool children in Santiago, Chile. Int. J. Odontostomat., 11(3):369-375, 2017.

eutróficos asistentes a jardines infantiles de Junji de la zona Oriente de Santiago. Arch. Latinoam. Nutr., 57(4):343-8, 2007.

Vázquez-Nava, F.; Vázquez-Rodríguez, E. M.; Saldívar-González, A. H.; Lin-Ochoa, D.; Martinez-Perales, G. M. \& Joffre-Velázquez, V. M. Association between obesity and dental caries in a group of preschool children in Mexico. J. Public Health Dent., 70(2):12430, 2010.

Willershausen, B.; Haas, G.; Krummenauer, F. \& Hohenfellner, K. Relationship between high weight and caries frequency in German elementary school children. Eur. J. Med. Res., 9(8):400-4, 2004.

Wu, L.; Chang, R.; Mu, Y.; Deng, X.; Wu, F.; Zhang, S. \& Zhou, D. Association between obesity and dental caries in Chinese children. Caries Res., 47(2):171-6, 2013.

Yévenes, L. I.; Zillmann, G. G.; Muñoz, M. A.; Mieres, A. V.; Coronado, V. L.; Manríquez, U. J.; Werlinger, C. F.; Maass, W. P. \& Quintana, B. R. Caries and obesity in 6 year-old schoolchildren from the Metropolitan region (MR) of Santiago, Chile. Rev. Odontol. Cienc., 27(2):121-6, 2012.

Zaror, S. C.; Pineda, T. P., Orellana, C. J. J. Prevalence of early childhood caries and associated factors in 2 and 4 year-old Chilean children. Int. J. Odontostomatol., 5(2):171-7, 2011.
Corresponding author:

Jenny Sánchez González

Cariology Area,

Department of Restorative Dentistry

Faculty of Dentistry

Universidad of Chile

Sergio Roberto Livingstone Polhammer 943

Independencia, Región Metropolitana

Santiago

CHILE

Email: jsanchez@odontologia.uchile.cl

Received: 25-05-2017

Accepted: 10-07-2017 